JPdK Volume 3 Nomor 2 Tahun 2021 Halaman 76-80

JURNAL PENDIDIKAN dan KONSELING

Research \& Learning in Primary Education

\title{
Analisis Kesulitan Siswa SMP Kelas 7 dalam Menyelesaikan Soal Cerita Operasi Aljabar Ditinjau dari Gender
}

\author{
Meliana Safitri $^{1}$, Hani’atul Mukharomah ${ }^{2}$, Syaikhotun Nakhlahul Dzahabiyyah $^{3}$, Febri Listianadewi ${ }^{4}$, \\ Linggar Riski Palupi ${ }^{5}$, Supratiwi Nursatamala ${ }^{6}$ Darmadi $^{7}$
}

\author{
Program Studi Pendidikan Matematika \\ Universitas PGRI Madiun dan \\ Email: melianasafitri750@gmail.com
}

\begin{abstract}
Abstrak
Penelitian ini dilatarbelakangi oleh hasil angket yang disebar secara random kepada siswa SMP kelas VII mengenai kesulitan yang dihadapi oleh siswa mengenai materi yang dihadapi. Dalam angket tersebut prosentase paling banyak siswa mengalami kesulitan dalam menyelesaikan soal cerita yaitu pada materi aljabar. Tujuan penelitian ini untuk mengetahui jenis kesulitan yang dihadapi siswa dalam menyelesaikan soal cerita pada materi aljabar yang ditinjau dari perbedaan gender. Penelitian ini menggunakan penelitian kualitatif dengan metode deskriptif. Pada angket yang disebarkan secara random ada 13 responden yang terdiri dari 7 siswa laki-laki dan 5 siswa perempuan serta diambil 2 siswa responden laki-laki dan 2 siswa perempuan untuk diteliti lebih lanjut. Dari 3 soal yang diberikan ditemukan beberapa kesulitan yang dibagi menjadi 3 indikator kesulitan yaitu: 1) kesulitan dalam mempelajari konsep, 2) kesulitan dalam menerapkan prinsip dan 3) kesulitan dalam menyelesaikan soal verbal. Pada siswa laki-laki tidak ditemukan kesulitan pada indikator 1 dan 2 sedangkan siswa perempuan pada indikator 1 dan 3. Rata-rata siswa laki-laki kesulitan dalam hal hasil akhir dan pada siswa perempuan kesulitan dalam mengaplikasikan konsep yang sudah diajarkan. Hal ini dipengaruhi salah satunya dipengaruhi oleh karakteristik otak laki-laki dan perempuan.
\end{abstract}

Kata kunci: analisis, kesulitan, gender

\begin{abstract}
This research was motivated by the results of questionnaires distributed randomly to seventh grade junior high school students regarding the difficulties faced by students regarding the material faced. In the questionnaire, the percentage of students who experienced difficulty in solving story problems, namely on algebraic material. The purpose of this study was to determine the types of difficulties faced by students in solving story problems on algebraic material in terms of gender differences. This research uses qualitative research with descriptive method. In the questionnaire distributed randomly there were 13 respondents consisting of 7 male students and 5 female students and 2 male respondents and 2 female students were taken for further research. From the 3 questions given, several difficulties were found which were divided into 3 indicators of difficulty, namely: 1) difficulties in learning concepts, 2) difficulties in applying principles and 3) difficulties in solving verbal problems. The male students did not find difficulties in indicators 1 and 2 while the female students in indicators 1 and 3. On average the male students had difficulties in terms of final results and the female students had difficulties in applying the concepts that had been taught. This is influenced, one of which is influenced by the characteristics of the male and female brailens.
\end{abstract}

Keywords: Keywords, analysis, trouble, gender. 


\section{PENDAHULUAN}

Matematika tidak hanya menjadi suatu pelajaran yang hanya dijumpai di dalam proses pembelajaran di sekolah dimana siswa hanya menghafal rumus-rumus yang telah disediakan atau menemukan nilai dari suatu soal yang diberikan, namun matematika dapat juga dijumpai dalam kehidupan sehari-hari dimana matematika memiliki peranan yang sangat penting dalam menyelesaikan suatu permasalahan dalam kehidupan sehari-hari. Oleh sebab itu, matematika memiliki hubungan yang sangat erat dalam kehidupan sehari-hari.

Menurut (Supriyanto, Mardiyana, \& Subanti, 2014) Alasan mengapa matematika perlu diajarkan kepada siswa adalah untuk membekali siswa dengan kemampuan berpikir logis, analisis sistematis, kritis dan kreatif, serta kemampuan memperoleh, mengelola, dan memanfaatkan informasi untuk bertahan hidup pada keadaan yang selalu berubah.

Selain itu Matematika menjadi sangat penting diajarkan di sekolah karena matematika itu merupakan bahasa. Sebagai bahasa, matematika wajib dipelajari agar manusia dapat menyelesaikan persoalan di kehidupan nyata dan berkomunikasi. Di samping itu matematika dapat membantu bidang studi lain. Berkomunikasi adalah salah satu keterampilan terpenting bagi masyarakat zaman teknologi dan informasi. Keterampilan tersebut memberikan kontribusi bagi siswa dalam berinteraksi sesama, merangsang penalaran dan membangun sosial bersama. (Nuralam \& Yani, 2019)

Beberapa karakteristik matematika yakni: (1) objek matematika adalah abstrak, (2) simbolsimbol kosong dari arti, (3) kesepakatan dan pemikiran deduktif aksiomatik, (4) taat asas atau kontradiksi, (5) kesemestaan sebagai pembatas pembahasan.

Dengan memperhatikan karakteristik matematika tersebut, tidak mustahil jika siswa dalam mempelajari matematika mengalami kesulitan. Kesulitan itu dapat terlihat dalam proses pemecahan soal-soal matematika. Fakta di lapangan menunjukkan bahwa salah satu kesulitan yang dialami siswa pada mata pelajaran matematika yaitu menyelesaikan soal cerita.

Pengertian soal cerita dalam mata pelajaran matematika adalah soal yang disajikan dalam bentuk uraian atau cerita, baik secara lisan maupun tulisan. Soal cerita wujudnya berupa kalimat verbal sehari-hari yang makna dari konsep dan ungkapannya dapat dinyatakan dalam simbol dan relasi matematika.

Memahami makna konsep dan ungkapan dalam soal cerita serta mengubahnya dalam simbol dan relasi matematika, sehingga menjadi model matematika bukanlah hal yang mudah bagi sebagian siswa. Berdasarkan hal tersebut, maka masalah (soal cerita) bukan hanya diberikan setelah teori matematikanya didapat oleh siswa, sehingga para siswa hanya belajar untuk mengaplikasikan pengetahuan matematika yang didapat, tidak pernah atau sedikit sekali mendapat kesempatan memecahkan masalah yang terkategori sebagai masalah proses.

Terkait dengan kemampuan siswa dalam menyelesaikan soal cerita aljabar, tiap siswa pasti memiliki kemampuan yang berbeda. Perbedaan tersebut bisa disebabkan oleh beberapa faktor, dan salah satu faktor tersebut adalah faktor perbedaan gender.

Perbedaan gender tentu menyebabkan perbedaan fisiologi dan mempengaruhi perbedaan psikologis dalam belajar, sehingga siswa laki-laki dan perempuan tentu memiliki banyak perbedaan dalam mempelajari matematika. Perbedaan gender dalam pendidikan di sekolah dapat terjadi dalam perolehan prestasi belajar. Biasanya gender ini tidak hanya berlangsung dan disosialisasikan melalui proses serta sistem pembelajaran di sekolah, tetapi juga melalui pendidikan dalam lingkungan keluarga.

Kemudian, matematika erat kaitannya dengan kehidupan sehari-hari seperti contohnya materi geometri (pengukuran), aritmatika sosial dan materi operasi aljabar. Salah satu materi yang harus dikuasai siswa yaitu operasi aljabar. Operasi aljabar adalah dasar dari perhitungan matematika.

Berpikir aljabar merupakan kemampuan seseorang untuk menganalisis situasi matematika dan struktur penggunaan simbol-simbol aljabar, menggunakan model matematika untuk mewakili hubungan situasi matematika dengan aljabar dan menganalisis perubahan dalam berbagai konteks. (Saputro \& Mampouw, 2018)

Pengertian aljabar sendiri yaitu suatu bentuk matematika yang diciptakan untuk mempermudah masalah-masalah dengan menggunakan huruf-huruf sebagai variabel yang Volume 4, No. 2, Maret 2021 pp 355-364 357 belum diketahui bilangannya dalam suatu perhitungan.

Materi ini terdapat pada mata pelajaran matematika kelas VII semester 1 yang mana pada usia SMP anak sudah mencapai usia kognitif berfikir semi formal. Siswa kelas VII masih berada dalam tahap peralihan usia kognitif dari SD yaitu berfikir konkret menjadi berfikir semi formal. Sehingga siswa dituntut untuk menyesuaikan tahap berfikir tersebut. Dalam prosesnya siswa mengalami kesulitan belajar, 
menurut Hidayati (Limardani, 2015) kesulitan belajar matematika yang dialami oleh siswa yaitu kesulitan dalam memahami bagian-bagian matematika tersebut.

Kesulitan yang dialami dapat berupa satu bagian ataupun lebih dari satu bagian matematika yang dipelajari. Seperti halnya pada suatu bahasan materi operasi aljabar, soal pertama dan beberapa soal selanjutnya mempunyai konsep yang sama. Jika siswa mengalami kesulitan di salah satu soal, maka hal tersebut juga dapat berdampak dalam proses pengerjaan soal yang lainnya.

Menurut Mardianto (2012), secara garis besar faktor-faktor yang menjadi penyebab timbulnnya kesulitan belajar yaitu: (1) Faktor internal siswa, yaitu hal-hal atau keadaan yang muncul dari dalam diri siswa sendiri; (2) Faktor eksternal siswa, yaitu hal-hal atau keadaan yang datang dari luar siswa. Berdasarkan uraian di atas, maka penulis ingin menganalisis kesulitan siswa SMP kelas VII dalam menyelesaikan soal operasi aljabar.

Penelitian ini membahas tentang kesalahan siswa dalam menyelesaikan soal cerita pada materi aljabar yang ditinjau dari gender, dimana penelitian ini mengambil siswa kelas VII SMP secara random untuk mendapatkan data yang valid. Perbedaan gender akan sangat berpengaruh pada data yang didapatkan, tentang cara mereka berpikir dan menyusun jawaban sesuai dengan urutan tingkatan pengerjaan. Elliot dkk merangkum perbedaan gender dari segi karakteristik sifat dalam tabel berikut (Suendang, 2017: 23):

Tabel 1. Perbedaan Gender dalam Beberapa Karakteristik Sifat

\begin{tabular}{|l|l|}
\hline Karakteristik & Perbedaan Gender \\
\hline Perbedaan & $\begin{array}{l}\text { Mayoritas perempuan menjadi } \\
\text { dewasa lebih cepat dari } \\
\text { laki-laki, tetapi ketika dewasa } \\
\text { laki-laki lebih besar dan } \\
\text { kuat dibanding perempuan }\end{array}$ \\
\hline $\begin{array}{l}\text { Perbedaan } \\
\text { Verbal }\end{array}$ & $\begin{array}{l}\text { Perempuan lebih baik dari laki- } \\
\text { laki dalam penggunaan } \\
\text { bahasa }\end{array}$ \\
\hline $\begin{array}{l}\text { Kemampuan } \\
\text { Spasial }\end{array}$ & $\begin{array}{l}\text { Laki-laki lebih unggul dalam } \\
\text { analisis ruang dan akan } \\
\text { terus terlihat selama sekolah }\end{array}$ \\
\hline
\end{tabular}

\begin{tabular}{|l|l|}
\hline Kemampuan & Terdapat lebih banyak \\
matematika & perbedaaan ketika tahun \\
& pertama \\
& sekolah menengah, laki-laki \\
& lebih baik dari pada \\
& perempuan \\
\hline Motivasi & Perbedaaan ini dihubungkan \\
& dengan tugas dan situasi. \\
& Laki-laki lebih baik dalam \\
& tugas-tugas maskulin seperti \\
& matematika dan sains, \\
& sedangkan perempuan lebih \\
& baik \\
& dalam tugas-tugas feminim \\
& seperti seni dan musik. \\
& Namun dalam kompetisi \\
& langsung antara laki-laki dan \\
& perempuan, ketika mulai \\
& memasuki masa dewasa, \\
& motivasi perempuan mendapat \\
prestasi menurun
\end{tabular}

Data yang sudah kami dapat, (Sholekah, Anggreini, \& Waluyo, 2017) kami analisis menggunakan beberapa indikator yang menurut kami relevan dengan penelitian ini yaitu:

Tabel 2 Indikator Kesulitan Siswa

\begin{tabular}{|l|l|l|}
\hline No & Indikator & Terjemahan \\
\hline 1. & $\begin{array}{l}\text { Kesulitan dalam } \\
\text { mempelajari konsep }\end{array}$ & $\begin{array}{l}\text { Siswa sulit dalam } \\
\text { mempelajari konsep } \\
\text { matematika dalam } \\
\text { menyelesaikan soal }\end{array}$ \\
\hline 2. & $\begin{array}{l}\text { Kesulitan dalam } \\
\text { menerapkan prinsip }\end{array}$ & $\begin{array}{l}\text { Siswa sulit dalam } \\
\text { menerapkan prinsip } \\
\text { yang telah ia dapatkan } \\
\text { dan sulit dalam } \\
\text { menerapkannya dalam } \\
\text { menyelesaikan soal }\end{array}$ \\
\hline 3. & $\begin{array}{l}\text { Kesulitan dalam } \\
\text { menyelesaikan } \\
\text { masalah }\end{array}$ & $\begin{array}{l}\text { Siswa sulit dalam } \\
\text { menyelesaikan soal- } \\
\text { soal yang verbal atau } \\
\text { soal-soal cerita }\end{array}$ \\
\hline
\end{tabular}

Tujuan penelitian ini dilakukan adalah untuk mendeskripsikan kesulitan-kesulitan yang dialami siswa dalam menyelesaikan soal cerita dalam operasi aljabar sesuai gender dan mendeskripsikan faktor yang menyebabkan kesulitan yang dialami siswa dalam menyelesaikan soal operasi aljabar. Kemudian, penelitian ini diharapkan dapat memberikan manfaat bagi peserta didik, bagi guru dan bagi peneliti untuk dapat mengetahui dan mengatasi kesulitan-kesulitan yang dialami oleh siswa.

Berdasarkan dari hasil observasi yang dilakukan pada 
siswa laki-laki dan perempuan di tingkat SMP melalui pengisian kuisioner dan latihan soal terkait operasi bentuk aljabar, peneliti memperoleh beberapa faktor yag mempengaruhi siswa dalam memecahkan soal cerita. Menurut (kallesta \& ervan, 2017) faktor yang menyebabkan siswa mengalami kesulitan dalam belajar bunyi terbagi kedalam dua faktor yaitu faktor internal dan faktor eksternal. Adapun faktor internal adalah: : 1) siswa masih kurang tertarik dengan pelajaran bunyi, 2) sikap siswa masih kurang dalam belajar bunyi, 3) siswa masih kesulitan mengerjakan soal bunyi, 4) perhatian siswa masih kurang, 5) usaha siswa masih kurang dalam belajar. Sedangkan faktor dari luar diri siswa yang mempengaruhi adalah: 1) guru masih kurang motivasi, 2) guru tidak menggunakan alat peraga, dan 3) jam masuk sekolah pada siang hari.

Selain itu proses berfikir antara laki-laki dan perempuan dalam memecahkan masalah matematika memiliki suatu perbedaan (siswandi, sujadi, \& riyadi, 2016). Menurut (siswandi, sujadi, \& riyadi, 2016, hal. 635) antara laki-laki dan perempuan memiliki suatu perbedaan dalam pemecahan masalah

matematika kontekstual. Perbedaan gender dalam pemecahan masalah matematika dapat

menjadi indikasi adanya sesuatu kesulitan yang berbeda yang dialami siswa laki-laki maupun perempuan.

Selama ini penelitian dibidang gender tidak lepas dari stereotip yang ada di masyarakat mengenai peran gender. Stereotip peran gender berarti bagian-bagian yang bersifat umum yang menggambarkan pandangan dan keyakinan tentang perempuan dan laki-laki. Ada banyak aspek yang diperhatikan diantaranya adalah lingkungan belajar dan respon siswa. (Dorisno, 2019)

\section{METODOLOGI PENELITIAN}

Penelitian ini memiliki langkah-langkah sebagai berikut, yaitu: 1) Membuat kuisioner kemudian disebar, kebeberapa siswa SMP kelas VII dengan latar belakang sekolah yang berbeda-beda. 2) Menyusun soal dari hasil kuisioner tersebut. 3) Menyebar soal dengan diberi batasan waktu pengerjaan. 4) Soal dikumpulkan. 5) Mengolah data yang sudah didapatkan menggunkan indikator yang relevan.

Penelitian ini dilakukan pada siswa laki-laki dan perempuan kelas VII tingkat SMP dengan mengambil sampel secara acak di berbagai kecamatan di kota Madiun. Selain itu langkah yang digunakan untuk mendapatkan data yaitu siswa diminta mengisi form secara daring dan mengerjakan 3 soal cerita terkait operasi bentuk aljabar.

Adapun teknik pengumpulan data dalam penelitian ini yaitu tes diagnostik matematika dan wawancara terhadap subjek penelitian. Tes Diagnostik Matematika. Tes adalah suatu teknik pengukuran yang di dalamnya terdapat berbagai pertanyaan, pernyataan atau serangkaian tugas yang harus dikerjakan atau dijawab oleh responden. Tes dalam penelitian ini menggunakan tes uraian/esai yang diberikan kepada siswa kelas 7 SMP sebagai responden. Selanjutnya hasil tes tersebut dikoreksi dan dianalisis guna untuk menentukan kesulitan-kesulitan yang dialami siswa.

Pedoman Wawancara Data. Untuk tes wawancara diperoleh dari hasil tes diagnostik siswa yang melakukan kesalahan dalam mengerjakan soal tes. Data tersebut dikelompokkan menjadi tiga yaitu kelompok siswa yang berkemampuan tinggi, sedang dan rendah. Tes wawancara dilakukan dengan bebas tidak terstruktur, dimana peneliti tidak menggunakan pedoman wawancara yang berisi pertanyaan yang akan diajukan, namun pertanyaan memuat poin penting yang ingin digali berdasarkan lembar jawaban dari responden. Tes wawancara dilakukan untuk mengetahui faktor-faktor yang mempengaruhi kesulitan siswa dalam menyelesaikan soal-soal pada materi aljabar.

Instrumen penelitian ini yaitu berupa tes diagnostik matematika dan pedoman wawancara pada pokok bahasan materi aljabar. Tes diagnostik dilakukan untuk mengetahui kesulitan siswa dalam menyelesaikan soalsoal pada operasi aljabar dan pedoman wawancara dilakukan untuk mengetahui faktor-faktor yang mempengaruhi kesulitan siswa dalam menyelesaikan soal operasi aljabar. Tes ini disusun oleh peneliti sesuai dengan materi yang telah dipelajari oleh siswa kelas 7 SMP.

Dalam penelitian ini teknik analisi data dilakukan dalam tiga tahapan, yaitu reduksi data, penyajian data, dan menarik kesimpulan. Adapun data yang digunakan dalam penelitian berasal dari tes diagnostik yang diberikan kepada siswa. 1) Reduksi data adalah kegiatan yang mengacu pada proses pemilihan, pemusatan perhatian, transformasi data "kasar" yang muncul dari catatan-catatan tertulis di lapangan. Dalam mereduksi data, tahapan yang dilakukan adalah debagai berikut: a) Menganalisis hasil jawaban siswa untuk menemukan kesulitan-kesulitan yang dilakukan siswa dalam menyelesaikan soal-soal operasi aljabar. b) Mengelompokkan kesulitan yang telah ditemukan pada tahap pertama yang disesuaikan dengan indikatorindikator kesulitan, yakni kesulitan konsep, kesulitan prinsip, dan kesulitan keterampilan (skill). 2) Penyajian Data. Setelah data direduksi, maka langkah selanjutnya 
yang dilakukan adalah menyajikan data. Penyajian data dilakukan dalam bentuk teks yang bersifat naratif. 3) Menarik Kesimpulan.

\section{HASIL PENELITIAN DAN PEMBAHASAN}

Berdasarkan jawaban yang dikirimkan siswa perempuan, peneliti menemukan bahwa siswa perempuan cenderung runtut dan jelas dalam menuliskan jawaban. Tetapi dalam hal mempelajari konsep siswa perempuan cenderung kurang teliti terbukti pada jawaban nomor 2 sehingga dapat dikatakan bahwa siswa perempuan masih kesulitan dalam mempelajari konsep. Sedangkan kesulitan dalam menerapkan prinsip siswa perempuan cenderung sudah baik terbukti dalam jawaban nomor

\section{SIMPULAN}

Dari uraian diatas dapat disimulkan bahwa siswa laki-laki cenderung kesulitan dalam menyelesaikan soal verbal dimana mereka kurang teliti dan tidak mengecek kembali hasil lakhir yang didapat. Sedangkan pada siswa perempuan kesulitan dalam menerapkan prinsip, dilihat dari siswa perempuan dalam menyelesaikan soal mereka mudah terkecoh dan belum bisa menganalisis serta belum bisa menerapkan konsep yang sudah dipelajari sebelumnya. Hal itu dipengaruhi oleh faktor internal dan faktor eksternal. Salah satu faktor internalnya adalah karakter dari gender (laki-laki dan perempuan).

\section{DAFTAR PUSTAKA}

Dorisno. (2019). Hubungan Gender dengan Kemampuan Pemecahan Masalah Matematika. Jurnal Tarbiyah Al-Awlad, 21.

Haqiqi, A. K. (2018). ANALISIS FAKTOR PENYEBAB KESULITAN BELAJAR IPA SISWA SMP. EduSains: Jurnal Pendidikan Sains \& Matematika, 37.

Kallesta, k. s., \& ervan, m. (2017). analisis faktor penyebab kesulitan belajar ipa fisika pada materi bunyi. jurnal pendidikan fisika, 1 .

Nashoba, d. r. (2019). PENGARUH GENDER TERHADAP KEMAMPUAN PEMECAHAN MASALAH SISWA KELAS VII PADA POKOK BAHASAN HIMPUNAN DIKONTROL DENGAN KEMAMPUAN BERPIKIR KRITIS DI MTs DARUL AMANAH. UNIVERSITAS ISLAM NEGERI WALISONGO (p. 19). SEMARANG: UNIVERSITAS ISLAM NEGERI WALISONGO.

Nuralam, N., \& Yani, M. (2019). Tipikal Gender Dalam Mengkomunikasikan Penyelesaian Masalah Matematika Sekolah Menengah
1 dan 3 siswa perempuan tersebut menuliskan diketahui, ditanya, dan dijawab serta permisalannya. Untuk kesulitan dalam menyelesaikan masalah verbal siswa sudah baik namun jika soal ceritanya terdapat kalimat pengecoh maka siswa perempuan tersebut masih belum mampu untuk menganalisis.

Berdasarkan jawaban yang dikirimkan siswa laki-laki, peneliti menemukan pada lembar jawaban siswa laki-laki jawabannya terlihat singkat. Langkah-langkah awal tidak ditulis secara rinci. Sehingga langsung merujuk pada jawaban akhir. Oleh sebab itu, diketahui bahwa siswa laki-laki banyak mengalami kesalahan dalam menentukan hasil akhirnya. Hal itu disebabkan atas ketidaktelitian siswa laki-laki dalam menyelesaikan soal dan tidak mengecek kembali hasil akhirnya.

Pertama. Prisma Sains, 101.

Saputro, G. B., \& Mampouw, H. L. (2018). Profil Kemampuan Berpikir Aljabar Siswa SMP Pada Materi Persamaan Linier Satu Variabel Ditinjau Dari Perbedaan Gender. Jurnal Numeracy, 78.

Sholekah , L. M., Anggreini, D., \& Waluyo, A. (2017). Analisis Kesulitan Siswa Dalam Menyelesaikan Soal Matematika Ditinjau Dari Koneksi Metematis Materi Limit Fungsi. Wacana Akademika, 155.

siswandi, e., sujadi, i., \& riyadi. (2016). analisis kesalahan siswa dalam menyelesaikan masalah matematika kontekstual pada materi segiempat berdasarkan analisis newman ditinjau dari perbedaan gender . jurnnal elektronik pembelajaran matematika, 1 .

Supriyanto, A., Mardiyana, \& Subanti, S. (2014). Karakteristik Berpikir Matematika Siswa SMP Majelis Tafsir Al-Qur'an (MTA) Gemolong Dalam Memecahkan Masalah Matematika Pada Materi Sistem Persamaan Linier Dua Variabel (SPLDV) Ditinjau Dari Kemampuan Penalaran Siswa Dan Gender. Jurnal Elektronik Pembelajaran Matematika, 1057. 